УДК 347.132

DOI: $10.33764 / 2687-041 X-2021-3-61-64$

\title{
ИССЛЕДОВАНИЕ ОТКАЗОВ В ОКАЗАНИИ ГОСУДАРСТВЕННОЙ УСЛУГИ ГОРОДА МОСКВЫ «СОГЛАСОВАНИЕ МЕЖЕВОГО ПЛАНА ГРАНИЦ ЗЕМЕЛЬНОГО УЧАСТКА»
}

\section{Александр Геннадьевич Проскурин}

Московский государственный университет геодезии и картографии, 105064, Россия, г. Москва, Гороховский пер., 4, аспирант, тел. (903)510-53-83, e-mail: alexander.proskurin95@gmail.com

\section{Александр Павлович Сизов}

Московский государственный университет геодезии и картографии, 105064, Россия, г. Москва, Гороховский пер., 4, доктор технических наук, зав. кафедрой кадастра и основ земельного права, тел. (906)716-27-10, e-mail: ap_sizov@mail.ru

В статье рассмотрены типичные ошибки кадастровых инженеров при подготовке межевых планов с целью внесения изменений в Единый государственный реестр недвижимости при прохождении мероприятий по согласованию местоположения границ земельных участков в рамках предоставления государственной услуги города Москвы «Согласования межевого плана границ земельного участка». На основе проведенного исследования автором выделены часто встречающиеся ошибки, которые в последствии приводят к отказу в предоставлении государственной услуги, а также сформированы предложения, которые могут способствовать исключению тих ошибок.

Ключевые слова: кадастр, межевой план, земельные участки, согласование местоположения границ, типичные ошибки

\section{THE STUDY OF REFUSALS IN THE PROVISION OF PUBLIC SERVICES OF THE CITY OF MOSCOW "COORDINATION OF A BOUNDARY PLAN FOR THE BOUNDARIES OF THE LAND"}

\section{Alexander G. Proskurin}

Moscow State University of Geodesy and Cartography, 4, Gorokhovsky Lane, Moscow, 105064, Russia, Student, phone: (903)510-53-83, e-mail: alexander.proskurin95@gmail.com

\section{Alexander P. Sizov}

Moscow State University of Geodesy and Cartography, 4, Gorokhovsky Lane, Moscow, 105064, Russia, D. Sc., Head of the Department of Cadastre and Foundations of Land Law, phone: (906)716-27-10, e-mail:ap_sizov@mail.ru

This article discusses typical errors of cadastral engineers when preparing land plans with the aim of amending the Unified State Register of Real Estate when taking steps to agree on the location of land boundaries as part of the provision of a public service in Moscow "Coordinating a land plan for land boundaries". Based on the study, the author identified frequently encountered errors that subsequently lead to the denial of the provision of public services, as well as suggestions that could help to eliminate these errors.

Keywords: cadastre, boundary plan, land plots, coordination of the location of borders, typical errors 
Предоставление государственной услуги города Москвы «Согласование межевого плана границ земельного участка» осуществляется в соответствии с Административным регламентом, утвержденным постановлением Правительства Москвы от 15.05.2012 № 199-ПП «Об утверждении административных регламентов предоставления государственных услуг Департамента городского имущества города Москвы» (далее - Постановление).

В соответствии с п. 2.10.1 Постановления основаниями для отказа в предоставлении государственной услуги являются:

1. Права на земельный участок либо права на расположенные на нем здания, строения, сооружения, оспариваемые в судебном порядке.

2. Невозможность предоставления государственной услуги по основаниям, предусмотренным федеральными законами и нормативными правовыми актами города Москвы.

3. Земельный участок, в отношении которого подготовлен межевой план, не имеет общих границ с земельными участками, находящимися в собственности города Москвы, либо земельными участками, государственная собственность на которые не разграничена.

4. Местоположение границ земельного участка, в отношении которого подготовлен межевой план, не соответствует утвержденной в установленном порядке схеме расположения земельного участка на кадастровой карте (плане) территории.

5. Местоположение границ земельного участка, в отношении которого подготовлен межевой план, определено с нарушением прав и законных интересов города Москвы.

Межевой план, наличие которого необходимо для оказания указанной государственной услуги, состоит из текстовой и графической частей, которые, в свою очередь, делятся на разделы, обязательные для включения в состав межевого плана, и разделы, включение которых в состав межевого плана зависят от вида кадастровых работ. Титульный лист и содержание обязательно входят в состав текстовой части межевого плана.

Существует семь видов межевых планов:

1. По уточнению границ и площади земельных участка;

2. По образованию земельных участков из земель государственной или муниципальной собственности;

3. По образованию земельного участка в результате выдела в счет доли (долей) в праве общей собственности;

4. По объединению земельных участков;

5. По перераспределению земельных участков;

6. По исправлению кадастровой ошибки земельных участков;

7. По разделу земельных участков.

Форма и состав сведений межевого плана регулируются приказом Минэкономразвития России от 08.12.2015 № 921 “Об утверждении формы и состава сведений межевого плана, требований к его подготовке”. 
На практике, при выполнении кадастровых работ кадастровыми инженерами, совершаются ошибки, которые рассмотрены ниже.

1. Ошибки при образовании земельных участков.

В соответствии со ст. 11.3 "Земельного кодекса Российской Федерации" от 25.10.2001 № 136-Ф3, «образование земельных участков из земель или земельных участков, находящихся в государственной или муниципальной собственности, осуществляется в соответствии с одним из следующих документов:

1) проект межевания территории, утвержденный в соответствии с Градостроительным кодексом Российской Федерации (далее - ПМТ);

2) проектная документация лесных участков;

3) утвержденная схема расположения земельного участка или земельных участков на кадастровом плане территории.»

В связи с тем, что у кадастровых инженеров не всегда есть возможность получить графическую часть ПМТ в электронном виде, формирование земельных участков по ПМТ нередко производится «на глаз», а полученные характерные точки границ земельных участков зачастую отличаются от утвержденных ПМТ.

Другой причиной несоответствия могут стать земельные участки, сведения о границах которых содержатся в Едином государственном реестре недвижимости (далее - ЕГРН).

Встречаются случаи, когда вновь образованный земельный участок приходится стыковать со смежными земельными участками, сведения о границах которых содержатся в ЕГРН для избегания чересполосицы, как это требует действующее земельное законодательство. Однако, смежные земельные участки, сведения о границах которых содержатся в ЕГРН, нередко не соответствуют границам, предусмотренным ПМТ.

Еще одной проблемой, с которой сталкиваются кадастровые инженеры при образовании земельных участков по ПМТ - это несоответствие фактического использования территории конфигурации земельного участка, предусмотренной ПМТ.

Учитывая изложенные факты, на основании п. 2.10.1.2 Административного регламента принимается решение об отказе в предоставлении государственной услуги в связи с невыполнением требования ст. 11.3 Земельного кодекса Российской Федерации.

2. Ошибки при уточнении земельных участков.

В соответствии с ч. 10 ст. 22 Федерального закона от 13.07.2015 № 218-Ф3 "О государственной регистрации недвижимости" (далее - Закон о недвижимости), при уточнении границ земельного участка их местоположение определяется, исходя из сведений, содержащихся в документе, подтверждающем право на земельный участок, а при отсутствии такого документа - исходя из сведений, содержащихся в документах, определявших местоположение границ земельного участка при его образовании.

В случае отсутствия в документах сведений о местоположении границ земельного участка его границами считаются границы, существующие на 
местности пятнадцать лет и более и закрепленные с использованием природных объектов или объектов искусственного происхождения, позволяющих определить местоположение границ земельного участка. На практике, перечисленные в Законе о недвижимости документы, позволяющее однозначно определить местоположение и конфигурацию границ земельного участка, у собственников земельных участков отсутствуют. В связи с изложенным, на основании п. 2.10.1.2 Административного регламента принимается решение об отказе в предоставлении государственной услуги в связи с отсутствием обоснований, предусмотренных ч. 10 ст. 22 Закона о недвижимости.

Для подтверждения существования границ земельного участка 15 и более лет и включения в состав межевого плана соответствующих документов, собственники земельных участков обращаются в Комитет по архитектуре и градостроительству города Москвы и в ГБУ города Москвы «Московский городской трест геолого-геодезических и картографических работ» («Мосгоргеотрест») для получения копии с цифрового топографического плана. По итогам обращения заявитель получает копию с цифрового топографического плана масштаба 1:2 000 испрашиваемого участка местности, на которой, как правило, изображен земельный участок.

При выполнении кадастровых работ кадастровыми инженерами нередко совершаются ошибки при образовании и при уточнении земельных участков. В целях их минимизации представляется необходимым разместить на официальных сайтах органов исполнительной власти электронную версию ПМТ, что позволит кадастровым инженерам получать координаты земельных участков, предусмотренных ПМТ.

При уточнении земельных участков включать в состав межевого плана следует: копии (фрагменты) исторических материалов на основе планов M 1:2000, материалы инженерно-геодезических изысканий, а также иные картографические материалы, свидетельствующие о прохождении границ земельного участка. В случае отсутствия перечисленных документов обоснованием могут послужить: абрисы характерных точек, материалы фотофиксации с обязательным указанием на них вновь образованных точек на местности.

В случае, если уточняемый земельный участок находится на праве аренды рекомендуется обращаться в орган исполнительной власти за выпуском Распоряжения.

\section{БИБЛИОГРАФИЧЕСКИЙ СПИСОК}

1. Постановление Правительства Москвы от 15.05.2012 № 199-ПП «Об утверждении административных регламентов предоставления государственных услуг Департамента городского имущества города Москвы».

2. "Земельный кодекс Российской Федерации" от 25.10.2001 № 136-ФЗ. 218-Ф3.

3. Федеральный закон "О государственной регистрации недвижимости" от 13.07.2015 №

4. Федеральный закон "О кадастровой деятельности" от 24.07.2007 № 221-Ф3.

5. Приказ Минэкономразвития РФ от 8 декабря 2015 г. № 921 «Об утверждении формы и состава сведений межевого плана, требований к его подготовке».

(C) А. Г. Проскурин, А. П. Сизов, 2021 